\title{
Soil Properties and Fertility Management within Ruiru Peri-Urban Area in Kiambu County, Kenya
}

\author{
${ }^{1}$ WASWA, F; ${ }^{2}$ MWAMBURI, M; ${ }^{3 *}$ WAKINDIKI, IIC; ${ }^{1}$ CHEMUTAI, R \\ ${ }^{1}$ Kenyatta University, School of Agriculture and Enterprise Development, P. O. Box 43844-00100, Nairobi \\ ${ }^{2}$ Taita Taveta University, School of Agriculture, Environment and Earth Sciences \\ ${ }^{3}$ University of South Africa, Department of Agriculture and Animal Health, Private Bag X6, Florida, South Africa. \\ * Correspondence Author Email: iwakindiki@gmail.com
}

\begin{abstract}
Peri-urban agriculture is a common practice around many towns and cities in Africa because of the ready urban market for farm commodities. However, it is constrained by a myriad of factors like lack of land tenure and poor soil fertility management strategies. This study focussed on soil physicochemical properties and fertility management in Ruiru Sub County, which is a peri-urban area, in Kiambu County of Kenya. Data was obtained from soil samples that were collected from ten small contact farms identified by the Sub-County Ministry of Agriculture and analysed for selected physicochemical parameters critical in soil fertility management. The results from this study indicated that most farmers were tenants growing leafy vegetables on small farms $\sim 0.1$ ha. Soil fertility was mainly maintained using organic manures, while tillage was done by hand. Both practices signal the limitations imposed by the small farm size and lack of land ownership. The soil $\mathrm{pH}$ was $6.3 \pm 0.87$, which was ideal for proton transfer reactions in the soil and availability of nutrients for plant uptake. Soil fertility was mostly limited by the interaction of soil $\mathrm{pH}, \mathrm{K}$ and $\mathrm{Ca}(30 \%)$, total $\mathrm{N}, \mathrm{OC}$ and $\mathrm{Zn}(27 \%)$ and $\mathrm{Cu}(15 \%), \mathrm{Mg}(10 \%)$ and $\mathrm{P}(9 \%)$. Therefore, the management of $\mathrm{Ca}$ fertilisation in this area is key because it is the $\mathrm{Ca}$ concentration of the soil solution that influences $\mathrm{K}$ and $\mathrm{pH}$ through ion exchange and $\mathrm{K}$ release.
\end{abstract}

DOI: https://dx.doi.org/10.4314/jasem.v24i5.17

Copyright: Copyright $\left({ }^{\circ} 2020\right.$ Waswa et al. This is an open access article distributed under the Creative Commons Attribution License (CCL), which permits unrestricted use, distribution, and reproduction in any medium, provided the original work is properly cited.

Dates: Received: 30 March 2020; Revised: 29 April 2020; Accepted: 10 May 2020

Key words: Organic manures, Inorganic fertilizers, Crop farming, Principle component analysis

Peri-urban farming is a reality that will not go away soon. Its main attraction is the ready market with better prices that is provided by the ever-rising urban populations especially in market towns (Mochache et al., 2020). Although it has significant potential to reduce poverty and increase food security and sovereignty in urban households (Chihambakwe et al., 2018) poor soil fertility management is a major cause for low crop productivity. Moreover, most farmers in peri-urban areas are squatters and are faced with urbanisation pressures (Opitz et al., 2016). Lack of land tenure for many peri-urban farmers makes soil fertility management even more complicated. For example, little attention is put on the diagnosis of soil fertility and requisite amelioration measures especially in developing countries (Bossio et al., 2010). However, routine use of organic manures based on tacit knowledge of crop husbandry is popular. Furthermore, safety of food grown in urban and periurban systems is compromised by use of polluted wastewater for irrigation. Therefore, an integrated approach in soil fertility management and food safety should inform the future of urban and peri-urban agroecosystems (Vanlauwe et al., 2014; Lal et al., 2015).
Nevertheless, evidence-based use of organic resources has potential to enhance urban food security commensurate with the increasing population (Decock et al., 2015). However, the choice and use of soil fertility management strategies by peri-urban growers is not only determined by profits but personal values such as happiness, comfortable life, independence, good health and achievement of life goals Okello et al., (2014). Macronutrients are often the focus by small-scale farmers in soil fertility management in the tropics. However, their availability from organic manures, which are the main source of plant nutrients in peri-urban cropping systems, often fluctuates and is low (Nciizah and Wakindiki, 2012a). Moreover, Bationo and Waswa (2011) noted that use of local available organic fertilizers was limited by their low quality and quantity, which supports the need for appropriate fortification. Whereas the contribution of macronutrients in soil fertility management in Africa is extensively studied, little is known about micronutrients. Nevertheless, there is evidence suggesting that micronutrients play a crucial role in plant nutrition. For example, Kihara et al., (2017) observed a $25 \%$ increase in maize yield when $\mathrm{S}$ and 
micronutrients were applied compared to macronutrient only treatment. It was concluded that sulphur and micronutrients limit crop yield in soils where response to macronutrients is low. Besides plant nutrients, the soil physical properties have a profound influence on soil fertility management, but they are less studied. Materechera (2016) studied soil properties and their constraints on peri-urban agriculture within Mahikeng city in the North West Province of South Africa. In that study it was found out that the effects of the soil physical properties extended to the subsoil. Most values of the physical properties were extreme thereby impeding plant root growth and necessitating deep ploughing and incorporation of organic matter. In this study it was hypothesised that the soil physicochemical properties have a similar effect on soil fertility. Therefore, the objective was to establish the effect of selected soil physicochemical properties on soil fertility management within Ruiru peri-urban area.

\section{MATERIALS AND METHODS}

The study area: This study was conducted in Ruiru Sub-County, a peri-urban area, which is in Kiambu County, Kenya. The area is about $1564 \mathrm{~m}$ above mean sea level, between $1.08^{\circ}$ Sand $1.15^{\circ}$ S: $36.96^{\circ} \mathrm{E}$ and $37.16^{\circ} \mathrm{E}$. Ruiru peri-urban area is about 201 square $\mathrm{km}$ and is divided into eight administrative wards namely; Mwiki, Mwihoko, Kiu, Kahawa-Wendani, Gatongora, Githotua, Biashara and Kahawa-Sukari (KNBS, 2019). Ruiru peri-urban area has a humid highland sub-tropical climate with distinct dry and wet seasons. The area receives about $1065 \mathrm{~mm}$ of bimodal annual rainfall. The wet seasons are between March and May and between October and December. The rest of the year is dry. The monthly mean temperature is $18.9^{\circ} \mathrm{C}$. Maximum temperature is about $24.9^{\circ} \mathrm{Cin}$ January and February while the minimum temperature is $13.0^{\circ} \mathrm{C}$ in July and August.

Socioeconomic characteristics in the Ruiru peri-urban area: Data on the socio-economic characteristics of sites was obtained from the respective contact farmers in the Wards using an interview schedule. Additional information was obtained key note respondents who were mainly the Ward Agricultural Officers. Data was obtained about farm size, land tenure, source of plant nutrients, tillage, and type of crops grown.

Soil sampling and analyses: Soil sampling was done from one cultivated plot (small farm) measuring $\sim 0.1$ ha in each ward except in Kahawa Sukari and Gatongora where two plots were sampled. The zigzag method (Beater, 1962) was used to sample soils from a depth of $0-200 \mathrm{~mm}$ using a soil auger. From each site, three subsamples were collected and bulked to obtain a representative composite sample. Each composite sample was put in a plastic bucket and labelled accordingly and then taken to the Kenya Agricultural and Livestock Research Organisation laboratories at Kabete in Nairobi for various physicochemical analyses. At the laboratory, each composite sample was spread on benches to dry at room temperature for a week. It was then sieved to pass through a $2 \mathrm{~mm}$ sieve, divided into three $\sim 1 \mathrm{~kg}$ subsamples and kept in airtight plastic bags and used for the analyses of the soil physicochemical properties. The soil samples were analysed for $\mathrm{pH}$, Organic carbon, total $\mathrm{N}$, available $\mathrm{P}$ and exchangeable bases: $\mathrm{Ca}, \mathrm{Mg}, \mathrm{K}$, and $\mathrm{Na}$. Micronutrients $\mathrm{Mn}, \mathrm{Cu}, \mathrm{Fe}$ and $\mathrm{Zn}$ were also determined. Standard procedures for soil analysis as described by Okalebo et al., (2002) were used.

Data analysis: Socioeconomic data was analysed using descriptive and inferential statistics (Freund and Wilson, 2003). The variability of the physicochemical properties in the study area was tested using Microsoft Excel (2007). Mean separations were done using Fisher's protected least significant differences (LSD) at $\mathrm{P} \leq 0.05$. Principal component analysis (Lever et al., 2017) was used to determine the relationships between the soil physicochemical properties with respect soil fertility. The Pearson product moment correlation coefficient (r) was used to measure the strength of linear dependence between the variables (Freund and Wilson, 2003).

\section{RESULTS AND DISCUSSION}

Socioeconomic characteristics in Ruiru peri-urban area: Farm size was either small or micro. Except in Gatongora ward where the farm size was $\sim 0.45 \mathrm{ha}$, the rest were $\leq 0.1$ ha. This farm size is typical of a periurban area that is almost turning into a full unban area. Gatongora ward had the largest farm size $(\sim 0.45 \mathrm{ha})$ compared to the rest of the wards $(\leq 0.1 \mathrm{ha})$ because it boarders the rural Kiambu county. All plots, except in Kahawa-Sukari and Gatongora, were either public, along streams or owned by absentee landlords. Soil fertility was maintained by adding organic manures and there was no evidence of using inorganic fertilizers. Land tenure influenced the latter because farmers were reluctant to invest in costly fertilizer input. Leafy vegetables, beans and maize were the main crops that were grown. The choice of the crops was influenced by the market demand habits of the non-farming urban and peri-urban working populations. Tillage was entirely done by hand because the small farm sizes limited mechanisation. Soil fertility in Ruiru peri-urban area: 
Table 1. Selected physicochemical properties of soils from the 10 sampled sites in the Wards

\begin{tabular}{|c|c|c|c|c|c|c|c|c|c|c|c|c|c|}
\hline \multirow[b]{2}{*}{ Site/Ward } & \multirow[b]{2}{*}{$\mathrm{pH}$} & \multicolumn{4}{|c|}{ meq $/ 100 \mathrm{~g}$} & \multicolumn{3}{|c|}{$\mathrm{g} / \mathrm{kg}$} & \multicolumn{4}{|c|}{$\mathrm{mg} / \mathrm{kg}$} & \multirow{2}{*}{$\begin{array}{l}\text { Soil } \\
\text { Texture }\end{array}$} \\
\hline & & $\mathrm{K}$ & $\mathrm{Ca}$ & $\mathrm{Mg}$ & $\mathrm{Na}$ & $* \mathrm{~N}$ & $\mathrm{OC}$ & $\mathrm{P}$ & $\mathrm{Mn}$ & $\mathrm{Cu}$ & $\mathrm{Fe}$ & $\mathrm{Zn}$ & \\
\hline Mwihoko 1 & 7.60 & 1.50 & 14.40 & 41.00 & 3.08 & 36.30 & 4.24 & 2.99 & 1.40 & 2.29 & 43.00 & 22.80 & Clay \\
\hline Mwihoko 2 & 6.20 & 0.90 & 7.90 & 30.00 & 0.80 & 17.30 & 3.56 & 1.32 & 1.18 & 1.12 & 68.10 & 4.18 & Clay \\
\hline Kahawa-Sukari & 6.80 & 1.50 & 16.80 & 190.00 & 2.16 & 11.40 & 4.03 & 0.70 & 0.65 & 2.27 & 65.60 & 18.00 & Clay \\
\hline Kahawa-Wendani & 5.80 & 2.30 & 24.80 & 45.00 & 1.42 & 21.90 & 4.18 & 0.56 & 4.18 & 1.79 & 138.00 & 30.40 & Clay \\
\hline Gatongora 1 & 6.80 & 1.20 & 11.90 & 45.00 & 1.24 & 12.70 & 2.06 & 1.54 & 0.25 & 1.47 & 81.20 & 3.69 & Clay \\
\hline Gatongora 2 & 6.50 & 1.70 & 17.90 & 45.00 & 1.28 & 21.00 & 4.09 & 0.68 & 0.61 & 2.12 & 76.10 & 4.72 & Clay \\
\hline Gitothua & 5.50 & 2.50 & 27.00 & 50.00 & 0.95 & 14.70 & 3.90 & 1.28 & 0.55 & 1.62 & 151.00 & 9.00 & Clay \\
\hline Kiu & 7.50 & 2.20 & 22.80 & 89.00 & 3.44 & 35.50 & 2.23 & 1.44 & 0.20 & 2.21 & 63.80 & 19.40 & Clay \\
\hline Biashara & 5.20 & 1.50 & 17.10 & 25.00 & 1.50 & 3.80 & 3.00 & 0.22 & 0.35 & 3.27 & 48.70 & 5.89 & Clay \\
\hline Mwiki & 5.30 & 1.70 & 17.60 & 130.00 & 0.60 & 13.00 & 4.00 & 1.40 & 0.65 & 1.80 & 145.00 & 9.36 & Clay \\
\hline Mean & 6.30 & 1.65 & 18.76 & 3.53 & 1.00 & 1.70 & 17.80 & 69.00 & 1.21 & 2.00 & 88.05 & 12.74 & Clay \\
\hline $\mathrm{SD}( \pm)$ & 0.87 & 0.95 & 10.38 & 0.82 & 0.76 & 0.50 & 5.82 & 52.80 & 1.18 & 0.59 & 40.70 & 9.29 & \\
\hline Variance & 0.76 & 0.91 & 107.69 & 0.66 & 0.59 & 0.3 & 3.38 & 2788 & 1.39 & 0.35 & 1662.08 & 86.32 & \\
\hline
\end{tabular}

Selected physicochemical properties of soils from the ten sampling sites in the eight wards used in this study are shown in Table 1. The soils were mostly acidic, and the dominant textural class was clay. Both macronutrients (e.g. phosphorus and calcium) and micronutrients (e.g. iron and zinc) exhibited high variability $(\geq 86.32)$. The high variability of these plant nutrients indicated that soil fertility management in the Ruiru peri-urban area is specific to the individual cultivated plot/small farm. Secondly, availability of plant nutrients; phosphorus, calcium, iron, and zinc varied from excess to inadequate. A tabulation of the results of the correlation coefficients between each pair of variables is presented in Table 2 .
The linear relationship between $\mathrm{pH}$ and other soil physiochemical properties was either strong with low probability $(\mathrm{K}: r=0.80, P=0.01$; $\mathrm{Ca}: r=0.75, P=$ 0.01; Fe: $r=-0.67, P=0.06$ and Na: $r=0.59, P=0.07$ ) or weak with high probability $(\mathrm{N}: r=-0.17, P=0.64$; OC: $r=-0.24, P=0.50$; P: $r=0.14, P=0.71 ; \mathrm{Mg}: r=$ -0.24, $P=0.51$; Mn: $r=-0.15, P=0.68$; Cu-: $r=0.03$, $P=0.92$; $\mathrm{Zn}: r=0.32, P=0.36)$.So, either way, the soil $\mathrm{pH}$ did not have significant linear relationship with the other soil physicochemical properties. The mean soil $\mathrm{pH}$ in the study area was $6.3 \pm 0.87$ (Table 2 ), which was within the preferred soil $\mathrm{pH}$ for the availability of most plant nutrients (Brady and Weil, 2008).

Table 2. Correlation coefficients $(r)$ between the soil physicochemical properties in the study area

\begin{tabular}{|c|c|c|c|c|c|c|c|c|c|c|c|c|c|}
\hline & Statistic & $\mathrm{pH}$ & ${ }^{2} \mathrm{~N}$ & $\mathrm{OC}$ & $\mathrm{P}$ & $\mathrm{K}$ & $\mathrm{Ca}$ & $\mathrm{Mg}$ & $\mathrm{Mn}$ & $\mathrm{Cu}$ & $\mathrm{Fe}$ & $\mathrm{Zn}$ & $\mathrm{Na}$ \\
\hline \multirow[t]{2}{*}{$\mathrm{pH}$} & $r$ & 1 & -0.17 & -0.24 & 0.14 & 0.80 & 0.75 & -0.24 & -0.15 & -0.03 & -0.67 & 0.32 & 0.59 \\
\hline & $P$ & & 0.64 & 0.50 & 0.71 & 0.01 & 0.01 & 0.51 & 0.68 & 0.92 & 0.06 & 0.36 & 0.07 \\
\hline \multirow[t]{2}{*}{$\mathrm{N}$} & $r$ & & 1 & 0.99 & 0.06 & 0.17 & 0.26 & 0.17 & 0.28 & 0.10 & 0.59 & 0.49 & -0.15 \\
\hline & $P$ & & & 0.00 & 0.87 & 0.64 & 0.47 & 0.65 & 0.43 & 0.77 & 0.07 & 0.15 & 0.67 \\
\hline \multirow[t]{2}{*}{$\mathrm{OC}$} & $r$ & & & 1 & 0.10 & 0.13 & 0.14 & 0.17 & 0.26 & 0.19 & 0.58 & 0.46 & -0.26 \\
\hline & $P$ & & & & 0.78 & 0.71 & 0.69 & 0.64 & 0.46 & 0.60 & 0.08 & 0.18 & 0.46 \\
\hline \multirow[t]{2}{*}{$\mathrm{P}$} & $r$ & & & & 1 & 0.16 & -0.12 & 0.17 & -0.20 & 0.06 & 0.11 & 0.22 & -0.10 \\
\hline & $P$ & & & & & 0.67 & 0.74 & 0.65 & 0.59 & 0.87 & 0.77 & 0.54 & 0.78 \\
\hline \multirow[t]{2}{*}{ K } & $r$ & & & & & 1 & 0.72 & -0.22 & -0.07 & 0.43 & -0.58 & 0.58 & 0.41 \\
\hline & $P$ & & & & & & 0.02 & 0.55 & 0.85 & 0.21 & 0.08 & 0.08 & 0.24 \\
\hline \multirow[t]{2}{*}{$\mathrm{Ca}$} & $r$ & & & & & & 1 & 0.04 & 0.21 & -0.10 & -0.22 & 0.57 & 0.65 \\
\hline & $P$ & & & & & & & 0.92 & 0.56 & 0.78 & 0.55 & 0.09 & 0.04 \\
\hline \multirow[t]{2}{*}{$\mathrm{Mg}$} & $r$ & & & & & & & 1 & 0.48 & -0.04 & 0.32 & 0.32 & 0.03 \\
\hline & $P$ & & & & & & & & 0.16 & 0.92 & 0.37 & 0.37 & 0.94 \\
\hline \multirow[t]{2}{*}{$\mathrm{Mn}$} & $r$ & & & & & & & & 1 & -0.19 & 0.35 & 0.70 & -0.10 \\
\hline & $P$ & & & & & & & & & 0.59 & 0.32 & 0.03 & 0.7 \\
\hline \multirow[t]{2}{*}{$\mathrm{Cu}$} & $r$ & & & & & & & & & 1 & -0.47 & 0.14 & -0.27 \\
\hline & $P$ & & & & & & & & & & 0.18 & 0.70 & 0.45 \\
\hline \multirow[t]{2}{*}{$\mathrm{Fe}$} & $r$ & & & & & & & & & & 1 & 0.09 & -0.18 \\
\hline & $P$ & & & & & & & & & & & 0.77 & 0.62 \\
\hline \multirow[t]{2}{*}{$\mathrm{Zn}$} & $r$ & & & & & & & & & & & 1 & 0.18 \\
\hline & $P$ & & & & & & & & & & & & 0.62 \\
\hline \multirow[t]{2}{*}{$\mathrm{Na}$} & $r$ & & & & & & & & & & & & 1 \\
\hline & $P$ & & & & & & & & & & & & \\
\hline
\end{tabular}

Total $\mathrm{N}$ had a significant positive linear relationship ( $r$ $=0.99$ ) with OC but with low $P$ value $(0.00)$. In general, total $\mathrm{N}$ content depends on the $\mathrm{OC}$ in the soil because up to $95 \%$ of soil total $\mathrm{N}$ comes from soil organic matter. Ideally OC in tropical clay soils could be as much as $30 \mathrm{~g} / \mathrm{kg}$ (Nciizah and Wakindiki, 2012b). In this study area with clay soil, OC was 17.8 $\pm 5.82 \mathrm{~g} / \mathrm{kg}$ (Table 1), which was below average and probably accounting for the low $P$ value. Moreover, most farmers were growing leafy vegetables, which 
left little organic matter available for decomposition after harvesting. The linear relationship between total $\mathrm{N}$ and rest of the physicochemical properties was weak (P: $r=0.06, P=0.87 ; \mathrm{K}: r=0.17, P=0.64$; Ca: $r=$ $0.26, P=0.47$; Mg: $r=0.17, P=0.65 ; \mathrm{Mn}: r=0.28$, $P=0.43$; Cu: $r=0.10, P=0.77$; Fe: $r=0.59, P=0.07$; $\mathrm{Zn}: r=0.49, P=0.15$; Na: $r=-0.15, P=0.67)$. Similar weak linear relationships were observed between OC, $\mathrm{P}, \mathrm{K}, \mathrm{Ca}, \mathrm{Mg}, \mathrm{Mn}, \mathrm{Cu}, \mathrm{Fe}, \mathrm{Zn}, \mathrm{Na}$, and the rest of the physicochemical properties (Table 2). From the foregoing, the linear relationship between the soil physicochemical properties was obscure. A multivariate model that was used in the principal component analysis (Lever et al., 2017) generated eigenvalues corresponding to each principal component. The eigenvalues represent a partition of the total variation. In this study, the first five principal components explained $94 \%$ of the cumulative variation observed among the sampled small farms (Table 3). Each of the five principal components had an Eigen value $>1.0$, which since the work by Kaiser (1960) has been the standard used to select principal components with influential variables.

Table 3. Summary statistics for principal component analysis

\begin{tabular}{lllllllllll}
\hline Statistics & \multicolumn{1}{l}{ Principal Component } \\
\cline { 2 - 12 } & 1 & 2 & 3 & 4 & 5 & 6 & 7 & 8 & 9 & 10 \\
\hline SD & 1.81 & 1.80 & 1.24 & 1.08 & 1.04 & 0.72 & 0.31 & 0.18 & 0.17 & 0.00 \\
POV & 0.30 & 0.29 & 0.14 & 0.11 & 0.10 & 0.05 & 0.01 & 0.00 & 0.00 & 0.00 \\
CP & 0.30 & 0.59 & 0.73 & 0.84 & 0.94 & 0.98 & 0.99 & 1.00 & 1.00 & 1.00 \\
EV & 3.56 & 3.29 & 1.78 & 1.20 & 1.13 & 0.65 & 0.29 & 0.08 & 0.03 & 0.00 \\
\hline
\end{tabular}

$* S D=$ Standard deviation Standard deviation, $P O V=$ proportion of variance, $C P=$ cumulative proportion; EV $=$ Eigenvalues

Table 4 Eigen vectors variables that contribute to the principle components

\begin{tabular}{|c|c|c|c|c|c|c|c|c|c|c|}
\hline \multirow[t]{2}{*}{ Variables } & \multicolumn{10}{|c|}{ Eigenvectors } \\
\hline & 1 & 2 & 3 & 4 & 5 & 6 & 7 & 8 & 9 & 10 \\
\hline $\mathrm{pH}$ & 0.4973 & 0.0232 & -0.0681 & 0.0535 & -0.1527 & -0.1659 & 0.3554 & 0.43 & -0.6053 & 0.0841 \\
\hline Total N & -0.0755 & -0.4774 & 0.198 & 0.3498 & 0.0056 & 0.1146 & 0.1229 & 0.1078 & 0.0569 & -0.4083 \\
\hline $\mathrm{OC}$ & -0.1128 & -0.4629 & 0.2739 & 0.2922 & 0.0043 & 0.0936 & 0.1191 & 0.2507 & 0.0269 & -0.0349 \\
\hline $\mathrm{P}$ & 0.0188 & -0.0735 & 0.2138 & -0.2463 & -0.8419 & -0.1879 & -0.0761 & -0.2017 & -0.0159 & -0.2891 \\
\hline K & 0.4804 & -0.1359 & 0.2499 & -0.001 & 0.0098 & -0.0443 & -0.0438 & 0.0787 & 0.387 & 0.3533 \\
\hline $\mathrm{Ca}$ & 0.4225 & -0.232 & -0.2039 & 0.1642 & 0.0746 & 0.1005 & 0.2931 & -0.7535 & -0.0396 & -0.0363 \\
\hline $\mathrm{Mg}$ & -0.1181 & -0.2463 & -0.2307 & -0.5458 & -0.1322 & 0.5998 & 0.3814 & 0.1426 & 0.0854 & 0.1391 \\
\hline Mn & -0.0622 & -0.3577 & -0.3054 & -0.3764 & 0.3398 & -0.3812 & -0.1058 & 0.0045 & -0.2138 & -0.374 \\
\hline $\mathrm{Cu}$ & 0.0939 & -0.0109 & 0.6235 & -0.2873 & 0.2501 & 0.3395 & -0.2807 & -0.1929 & -0.4744 & -0.0085 \\
\hline $\mathrm{Fe}$ & -0.3621 & -0.2996 & -0.2087 & 0.2615 & -0.2213 & 0.0085 & -0.2374 & -0.1686 & -0.404 & 0.5513 \\
\hline $\mathrm{Zn}$ & 0.2152 & -0.4482 & -0.0141 & -0.2804 & 0.0192 & -0.2667 & -0.3309 & 0.0862 & 0.1909 & 0.2835 \\
\hline $\mathrm{Na}$ & 0.3472 & 0.0074 & -0.3903 & 0.1804 & -0.1319 & 0.4601 & -0.5912 & 0.1802 & -0.0189 & -0.2677 \\
\hline
\end{tabular}

The most important variables in principal component one were $\mathrm{pH}, \mathrm{K}$ and $\mathrm{Ca}$, based on their positive influence (Table 4; Figure 1). This was probably because $\mathrm{pH}$ is a soil solution buffer for all proton transfer reactions in the soil (Brady and Weil, 2008). Furthermore, $\mathrm{Ca}$ concentration of the soil solution influences $\mathrm{K}$ and $\mathrm{pH}$ through ion exchange and $\mathrm{K}$ release or fixation (Schneider, 2008). Calcium concentration in the soil solution in this study area was $18.76 \pm 10.38 \mathrm{meq} / 100 \mathrm{~g}$, which was ideal to affect $\mathrm{K}$ release from the available pools under the prevailing soil $\mathrm{pH}$ of $6.3 \pm 0.87$ (Table 1). Total N, OC and $\mathrm{Zn}$ had a high negative influence on principal component two (Table 4; Figure 1). Whereas the association between total $\mathrm{N}$ content and $\mathrm{OC}$ in the soil is naturally positive (Brady and Weil, 2008), their interaction with Zn was not clear. So, management $\mathrm{Zn}$ micronutrient and organic matter in the study area is of interest. Alternatively, $\mathrm{Zn}$ influenced soil fertility when OC content was below average in the soil.

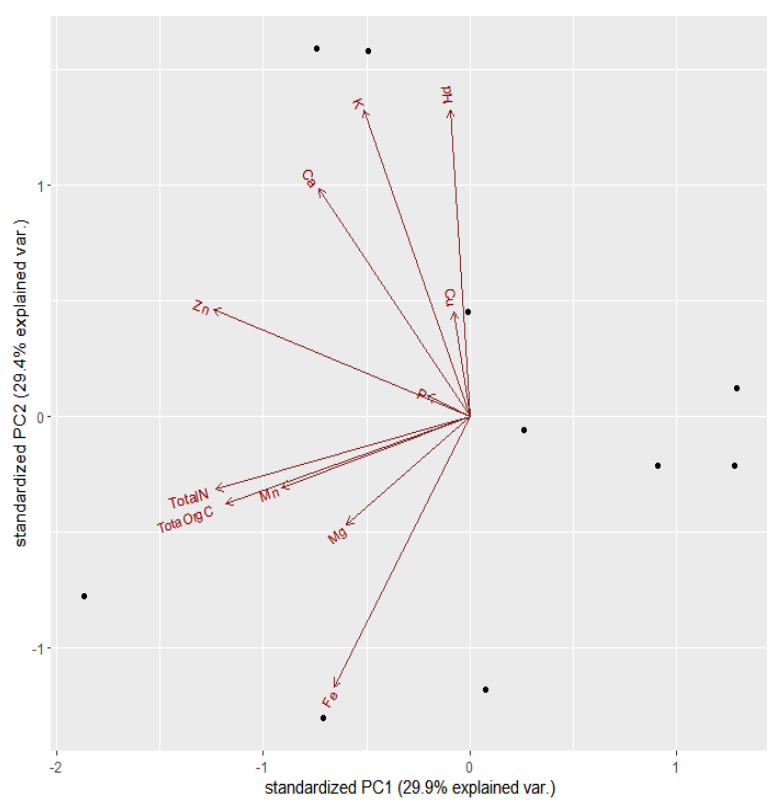

Fig 1. Two-dimensional relationships of the soil physicochemical properties between $\mathrm{PC} 1 \& 2$ 
Copper had a strong influence on component three while $\mathrm{Mg}$ strongly influenced component four (Table 4; Figure 1). Copper is known to influence Fe and Mn concentrations in the soil as well as to be affected by $\mathrm{N}$ and $\mathrm{P}$ (component five) while $\mathrm{Mg}$ is affected by $\mathrm{K}$ and Ca (Brady and Weil, 2008), which were instrumental in component one. Phosphorous had the highest effect of any of the variables, and this was in component five (Table 4; Figure 1). The fact that $\mathrm{P}$ does not have a strong influence on either component one or two suggests that its quantities (69 $\pm 52.80 \mathrm{mg} / \mathrm{kg}$ ) in soil was adequate. Nonetheless $\mathrm{P}$ concentration in the soil is influenced by $\mathrm{Ca}$ (component one) and $\mathrm{Fe}$ while it affects $\mathrm{K}$ (component one) and micronutrients $\mathrm{Fe}, \mathrm{Cu}$ (component three) and Zn (component two) (Brady and Weil, 2008).

Conclusions: Calcium, potassium and soil $\mathrm{pH}$ were responsible for proton transfer reactions in the soil, while organic carbon, Nitrogen and Zinc were strongly associated with soil organic matter content and micronutrient Zinc. Soil reaction, $\mathrm{Ca}$ fertilisation and organic carbon management deserve closer attention in the study area.

Acknowledgements: The authors wish to acknowledge the kind support of Kenyatta University Vice Chancellor Grant 2017 and Kiambu County Government for assistance in data collection.

\section{REFERENCES}

Bationo, A; Waswa, BS (2011). New challenges and opportunities for integrated soil fertility management in Africa. In: Bationo A; Waswa B; Okeyo JM: Maina F; Kihara J (ed) Innovation as Key to the Green Revolution in Africa. Exploring the Scientific Facts Vol 1. New York, Springer

Beater, BA (1962). The sampling and analyses of field soils. South African Sugar Association, Experimental Station, Mount Edge Combe, Natal, South Africa.

Bossio, D; Geheb, K; Critchley, W (2010). Managing water by managing land: addressing land degradation to improve water productivity and rural livelihoods. Agr. Water Mngt. 97(4): 536 542 .

Brady, NC; Weil, RR (2008). The nature and properties of soils. $14^{\text {th }}$ ed. Prentice Hall, Upper Saddle River, NJ.

Chihambakwe, M; Mafongoya P; Jiri, O (2018). Urban and Peri-Urban Agriculture as A Pathway to Food Security: A Review Mapping the Use of Food Sovereignty. Chal 10(1): $1-12$.

Decock, C; Lee, J; Pereira, E; Necpalova, M; Tendall, D; Six, J (2015). Mitigating $\mathrm{N}_{2} \mathrm{O}$ emissions from soil: from patching leaks to transformative action. Soil 1(2): $687-694$.

Freund, RJ; Wilson, WJ (2003). Statistical methods. $2^{\text {nd }}$ Edn. Elsevier Science, USA

Kaiser, HF (1960). The application of electronic computers to factor analysis. Educ. Psychol. Meas 20(1): 141-151.

Kenya National Bureau of Statistics (2019). Kenya Population and Housing Census: Vol II. Distribution of Population by Administrative Units.

Kihara, J; Sileshi, GW; Nziguheba, G; Kinyua, M; Zingore, S; Sommer R (2017). Application of secondary nutrients and micronutrients increases crop yields in sub-Saharan Africa. Agron. Sustain. Dev 37(25): 1 - 14.

Lal, K; Minhas, PS; Yadav, RK (2015). Long-term impact of wastewater irrigation and nutrient rates II. Nutrient balance, nitrate leaching and soil properties under peri-urban cropping systems. Agr. Water Mngt 156 (1): 110-117.

Lever, J; Krzywinski, M; Altman, N (2017). Points of significance: Principal component analysis. Nat Methods 14(7): 641 - 642.

Materechera, SA (2018). Soil properties and subsoil constraints of urban and peri-urban agriculture within Mahikeng city in the North West Province (South Africa). J Soil Sediment 18(2): 494 - 505.

Mochache, M; Yegon, R; Wakindiki, IIC (2020). Market town household solid waste management: A case study of Embu, Kenya. J. Appl. Environ. Manage 24(1): 105 - 109.

Nciizah, AD; Wakindiki, IIC (2012a). Aggregate stability and strength of a hard-setting soil amended with cattle manure. Afr. J. Agric. Res $7(1): 68-73$.

Nciizah, AD; Wakindiki, IIC (2012b). Particulate organic matter, soil texture and mineralogy relations in some Eastern Cape ecotopes in South Africa. S. Afr. J. Plant Soil. 29(1): 39 - 46. 
Okalebo, JR; Gathua, KW; Woomer, PL (2002). Laboratory methods of soil and plant analysis: a working manual second edition. TSBFCIAT and SACRED Africa. Nairobi, Kenya.

Okello, JJ; Largerkvist, CJ; Ngigi, MW; Karanja N (2014). Means-end chain analysis explains soil fertility management decisions by peri-urban vegetable growers in Kenya. Int. J. Agr. Sustain 12(2): 183-199.

Opitz, I; Berges, R; Piorr, A; Krikser, T (2016). Contributing to food security in urban areas: differences between urban agriculture and periurban agriculture in the Global North. Agric. Hum. Values 33 (2): 341 - 358.
Schneider, A (2008). Influence of soil solution Ca concentration on short-term $\mathrm{K}$ release and fixation of a loamy soil. Eur. J. Soil Sci. 48(3): 513 - 522.

Shen, J; Yuan, L; Zhang, J; Li, H; Bai, Z; Chen, X; Zhang, W; Zhang, F (2011). Phosphorus dynamics: From soil to plant. Plant Physiol. 156(3): $997-1005$.

Vanlauwe, B; Coyne, D; Gockowski, J; Hauser, S; Huising, J; Masso, C; van Asten, P (2014). Sustainable intensification and the African smallholder farmer. Curr. Opin. Env. Sust 8(0) 15 -22 . 